\title{
Induced Breeding of Striped Spiny Eel, Mastacembelus Pancalus: Considering Various Doses of Pituitary Gland
}

\section{Hormone}

\section{Islam MS * and Biswas K}

Department of Fisheries and Marine Bioscience, Jessore University of Science and Technology, Jessore-7408, Bangladesh

${ }^{*}$ Corresponding author: Md. Sherazul Islam, Associate Professor, Department of

Fisheries and Marine Bioscience, Faculty of Biological Science and Technology, J Technology, Jessore-7408, Bangladesh, Tel: +88-01913241344; E-mail: tuhinkk@yahoo.com; kallanibiswas@yahoo.com

\section{Abstract}

The induced breeding of the striped spiny eel Mastacembelus pancalus using PG hormone was done to develop breeding protocol of the species and the optimization of doses. The present study consisted of two trials and each trial had three treatments $\left(\mathrm{T}_{1}, \mathrm{~T}_{2}\right.$ and $\left.\mathrm{T}_{3}\right)$ with three replications of each. In first trial (double dose) fishes were injected with two separate doses of pituitary gland (PG) hormone. In the preliminary dose, females were injected at 55, 60 and 65 mg.kg-1 and in resolving dose, injected 105,120 and $135 \mathrm{mg} \cdot \mathrm{kg}^{-1}$ body weight in $\mathrm{T}_{1}, \mathrm{~T}_{2}$ and $\mathrm{T}_{3}$ respectively. In second trial (single dose) fishes were injected only once at 160, 180 and $200 \mathrm{mg} \cdot \mathrm{kg}^{-1}$ body weight in $\mathrm{T}_{1}, \mathrm{~T}_{2}$ and $\mathrm{T}_{3}$ respectively. In both trials, males were injected at 55, 60 and $65 \mathrm{mg} \cdot \mathrm{kg}^{-1}$ body weight in $\mathrm{T}_{1}, \mathrm{~T}_{2}$ and $\mathrm{T}_{3}$ respectively. The water parameters such as water temperature, $\mathrm{pH}$ and DO were ranged from 26.5 to $31.2^{\circ} \mathrm{C}, 7.06$ to 8.04 and 4.1 to $5.6 \mathrm{mg} \cdot \mathrm{L}^{-1} \mathrm{respectively} \mathrm{which} \mathrm{was}$ not significantly $(\mathrm{p}<0.05)$ differ in different treatments in both trials. It is showed the male start to chase with female after 9-10 h of hormone injection and spawning take place after 7-9 $\mathrm{h}$ of chasing. It is showed that there were no significant differences in respect of spawning and incubation period in two trials and fishes were spawned $100 \%$ in all treatments. Spawning time and incubation period were ranged from 15 to $20 \mathrm{~h}$ and 36 to $41 \mathrm{~h}$ respectively in both trials. The treatment 2 of $1^{\text {st }}$ trial showed significantly $(\mathrm{p}<0.05)$ higher performance in terms of fertilization rate $(73.33 \%)$ and hatching rate $(67.85 \%)$ than other treatments which suggested that PG dose $\left(1^{\text {st }} \mathrm{dose} 60 \mathrm{mg} \cdot \mathrm{kg}^{-1}+2^{\text {nd }} \mathrm{dose} 120 \mathrm{mg} \cdot \mathrm{kg}^{-1}\right.$ body weight) could be better for inducing of M. pancalus.

Keywords: Induce breeding; Mastacembelus pancalus; PG hormone; Breeding behavior; Dose optimization

\section{Introduction}

There are three species such as Mastacembelus pancalus (local name: Guchi baim), Macrognathus aculeatus (local name: tara baim) and Macrognathus armatus (local name: shal baim) under Mastacembalidae family found in Bangladesh [1]. The Striped spiny eel ( $M$. pancalus Hamilton, 1822) is one of the common species of 


\section{International Journal of Oceanography \& Aquaculture}

the family and important eel fish in Bangladesh with great demand as a good traditional table fish. The species is distributed to India, Pakistan, and Bangladesh [2].

The demand of the species always exceeds the supply and the supply mostly depends on the captures resources. Guchi baim was available in rivers, canals, beels and inundated fields in the past throughout Bangladesh but presently it is under threat due to tremendous loss of natural habitat [3]. Though in last assessment of IUCN Bangladesh the fish is under category of 'least concern' but it was reported as 'critically endangered' by IUCN Bangladesh [4,5]. The fish is not yet reported as culturable fish in the country. The main reasons behind this are the insufficient information on the captive breeding, inadequateness of natural fry and absence of commercial hatchery production seed [6]. Therefore, it becomes necessary to take up induce breeding of the fish. Knowledge of the reproductive biology of fish is essential for evaluating the commercial potentiality of its stock, life history, culture practice and management of its fishery [7].

Induced breeding is the most significant advancements in the field of aquaculture and is a technique to stimulate ripe fish breeders by pituitary gland (PG) hormone or any other synthetic hormone to breed in captive condition by promotion of timely release of sperms and eggs [8] Pituitary gland secretes the gonadotropins i.e., Follicle Stimulating Hormone (FSH) and Luteinising Hormone (LH) which act as maturation of ovarian follicles and luteinisation in females and spermatogenesis in the testes of males. However, there is great variability in its effectiveness in different species [8].

Notable works have been done on striped spiny eel such as worked on the biology and fisheries [9]; on the reproductive biology [10-13]; on the food and feeding habits [14]; on the fecundity [15]; on the embryonic and larval development $[16,17]$; and on the captive breeding of the species considering the various hormonal responses $[3,6,18]$. However, there is no such details work on the dose optimization of a specific hormone of the particular species except $[3,18]$ who studied on the dose optimization and effects of PG on artificial propagation of $M$. pancalus. The all other experiments conducted with PG dose that injected in two times. The present study was the first time conducted to optimize the PG dose for the species in two different trials as I) Hormone injected in preliminary and resolving dose and II) administrated total hormones at single time i.e. no preliminary dose. The breeding behavior of the species also observed during the study.

\section{Materials and Methods}

\section{Study Site}

The study was conducted in the laboratory of Department of Fisheries and Marine Bioscience, Jessore University of Science and Technology, Jessore, Bangladesh. All the preparations needed for induced breeding of M. pancalus were done in the laboratory. The aquarium set up, water supply facilities; instruments required for hormone administration and working space were assured before the breeding program. The experiment was done from April to July, 2016.

\section{Aquariums setup}

The rectangular glass aquariums (36 inches $\mathrm{x} 15$ inches $x 14$ inches) were used for both rearing and spawning of fish. The aquariums were supported with sand, gravel and bamboo slits, used as fish hiding place. The water hyacinth was supplied to hold the sticky eggs. All spiny eels appreciate floating plants.

\section{Measurement of Water Quality}

The water quality of the experimented aquarium were maintained and recorded carefully. Water parameters such as dissolved oxygen (DO), $\mathrm{pH}$ and water temperature were measured weekly during brood fish rearing and daily during induces. A pH meter (EZo DO; Model-7200; Made in Taiwan) was used for the measurement of $\mathrm{pH}$ and temperature; a DO meter (LT Lutron; Model- YK-22 D0; Made in Taiwan) was used for the measurement of DO. The water was exchanged daily at $20 \%-30 \%$ by siphoning so that excessive amount of iron, carbonate and other wastes were not accumulated at the bottom of the tank.

\section{Collection and Rearing of Brood Fish}

Samples of $M$. pancalus for induced breeding were collected from local fishermen at Joghati baor, Jessore Sadar. The fishes were reared in aquarium about one month (Figure 1). Tubefex was given twice as feed daily at early morning and evening according to their demand.

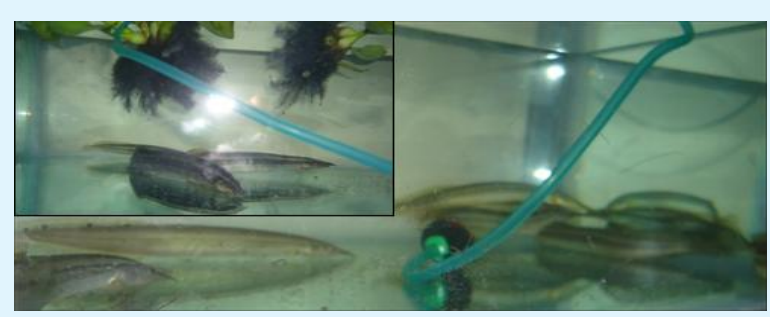

Figure1: Rearing of broods M. pancalus in the aquarium condition. Used water hyacinth and aeration (inset). 


\section{International Journal of Oceanography \& Aquaculture}

\section{Selection of Broods and Pairing}

Selection of brood fish is the main task on which successful spawning mostly depends. Improper selection of brood may result poor quality or fish may not spawn at all. Mature and healthy fishes were selected by observing morphological symptoms like swollen and enlarge abdomen for female and slender-shaped, smaller in size at the same batch with whitish belly for male. The body weight of individuals was measured by using electric weight balance (A\&D Company. Ltd; Model-EK 1200I; Made in Japan) and noticed average body weight $9.00 \pm$ $1.2 \mathrm{~g}$. The selected broods were kept in separated experiment aquarium at sex ratio 1:1 for male and female for pairing and conditioning for3-4 days.

\section{Experimental Design}

The experimental fish was induced with pituitary gland (PG) hormone in two different trials and each trial had three treatments $\left(\mathrm{T}_{1}, \mathrm{~T}_{2}\right.$, and $\left.\mathrm{T}_{3}\right)$ with three replications of each. In first trial (double dose) fishes were injected with two separate doses (Table 1). The resolving dose $\left(2^{\text {nd }}\right.$ dose) received double amount of PG of the preliminary dose ( $1^{\text {st }}$ dose). In the $2^{\text {nd }}$ trial, fishes were induced with single dose of hormone and the amount of PG was the equivalent to the total amount of PG applied in 1st trial (Table 1).

\begin{tabular}{|c|c|c|c|c|}
\hline \multirow{2}{*}{ Treatment } & \multirow{2}{*}{ Sex } & \multicolumn{2}{|c|}{$\mathbf{1}^{\text {st }}$ trial } & $\mathbf{2}^{\text {nd }}$ trial \\
\cline { 2 - 5 } & & Preliminary dose $\mathbf{( m g} \cdot \mathbf{k g}-\mathbf{1}$ ) & Resolving dose (mg-kg-1) & Single dose (mg-kg-1) \\
\hline \multirow{2}{*}{$\mathrm{T}_{1}$} & Female & 55 & 105 & 160 \\
\cline { 2 - 5 } & Male & - & 55 & 55 \\
\hline \multirow{2}{*}{$\mathrm{T}_{2}$} & Female & 60 & 120 & 180 \\
\cline { 2 - 5 } & Male & - & 60 & 60 \\
\hline \multirow{2}{*}{$\mathrm{T}_{3}$} & Female & 65 & 135 & 200 \\
\cline { 2 - 5 } & Male & - & 65 & 65 \\
\hline
\end{tabular}

Table1: The brief experimental design of $1^{\text {st }}$ trial and $2^{\text {nd }}$ trial of induces of $M$ pancalus using PG extract.

In $1^{\text {st }}$ trial, the resolving dose applied after $6 \mathrm{~h}$ of preliminary dose.

\section{Hormone Administration}

The brood fish were collected for hormone administration very carefully and wrapped with soft and moist cloth. The needle was pushed at the basal part of dorsal fin at an angle of $45^{\circ}$ with the body (Figure 2). The amount of hormone for each fish was determined before according to the body weight of the broods. After the administration of hormones, the fishes were kept in separate aquarium at the sex ratio of 1:1 for natural propagation. The fishes were observed carefully at every 15 min with naked eye for any behavioral changes and spawning activity i.e. their body coloration, change of position, chasing behavior up to spawning time.

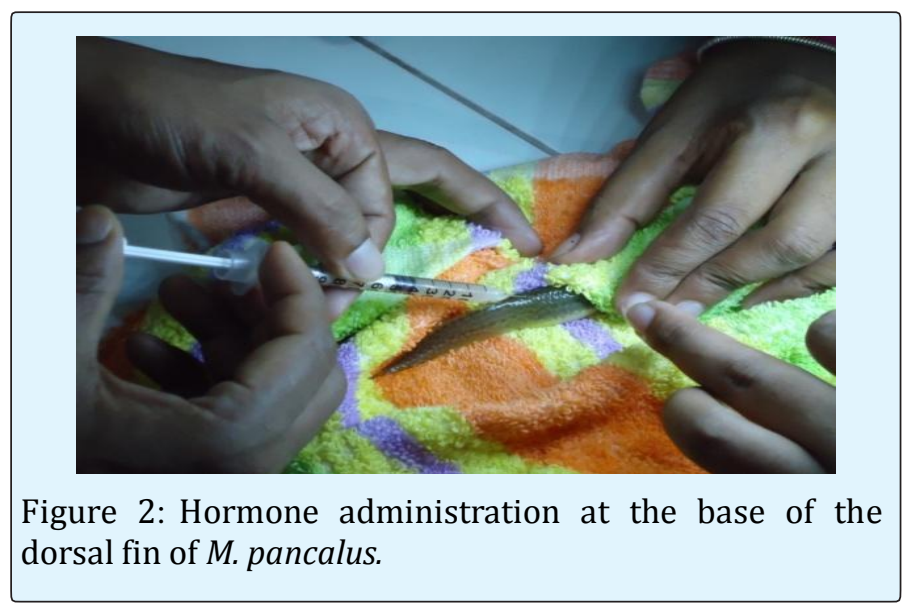

\section{Determination of Fertilization Rate}

The eggs were attached with the roots of water hyacinths in the aquarium. To determine the fertilization rate 10 eggs was taken from each replication of different treatment and placed in a Petridis containing water. Then the collected eggs were observed under a microscope (Carl Zesis microscopy GMBH, S.N. MKG8639, made by Germany) and fertilized eggs were counted and fertilization rate was calculated by following formula. The fertilized eggs were recognized as their transparent shell from the unfertilized eggs which were opaque.

$$
\text { Fertilization rate }(\%)=\frac{\text { No. of fertilized eggs }}{\text { Total no. of eggs }} \times 100
$$

\section{Determination of Hatching Rate}

The hatching rate was the portion of the fertilized eggs that came out as developing larvae and was determining by counting the number of larvae from predetermined number of fertilized eggs. The hatching rate was calculated by the following formula:

$$
\text { Hatching rate }(\%)=\frac{\text { No of hatchlings }}{\text { Total number of fertilized eggs }} \times 100
$$

\section{Statistical Analysis}

The results found in the study were subjected to statistical analysis, chi-square test that showed the 


\section{International Journal of Oceanography \& Aquaculture}

significance $(\mathrm{P}<0.05)$ level of differences between the treatments. This statistical analysis was performed with the aid of the Microsoft Excel.

\section{Results}

\section{Water Quality}

The physico-chemical condition such as temperature,
$\mathrm{pH}$ and dissolved oxygen (DO) of water in experimental aquariums under different treatments of the two trials is presented in table 2 . The water temperature, $\mathrm{pH}$ and $\mathrm{DO}$ were ranged from 26.5 to $31.1^{\circ} \mathrm{C}, 7.06$ to 8.04 and 4.1 to $5.6 \mathrm{mg} \cdot \mathrm{L}^{-1}$ respectively in $1 \mathrm{st}$ trial and 28.7 to $31.2^{\circ} \mathrm{C}, 7.56$ to 7.98 and 4.2 to $5.4 \mathrm{mg} \cdot \mathrm{L}^{-1}$ at $2^{\text {nd }}$ trial. The recorded water parameters were not significantly $(\mathrm{p}<0.05)$ different between treatments of the both trials.

\begin{tabular}{|c|c|c|c|c|}
\hline Trial & Parameters & $\mathbf{T}_{\mathbf{1}}$ & $\mathbf{T}_{\mathbf{2}}$ & $\mathbf{T}_{\mathbf{3}}$ \\
\hline \multirow{3}{*}{$\vec{\sim}$} & Temperature $\left.{ }^{\circ} \mathrm{C}\right)$ & $28.39 \pm 1.12$ & $28.43 \pm 1.16$ & $28.48 \pm 1.61$ \\
\cline { 2 - 5 } & $\mathrm{pH}$ & $7.73 \pm 0.34$ & $7.73 \pm 0.11$ & $7.80 \pm 0.09$ \\
\cline { 2 - 5 } & DO $\left(\mathrm{mg} \cdot \mathrm{L}^{-1}\right)$ & $4.67 \pm 0.45$ & $4.98 \pm 0.46$ & $4.85 \pm 0.38$ \\
\hline \multirow{3}{*}{$\approx$} & Temperature $\left.{ }^{\circ} \mathrm{C}\right)$ & $29.99 \pm 0.7$ & $29.51 \pm 0.44$ & $29.96 \pm 0.62$ \\
\cline { 2 - 5 } & $\mathrm{pH}$ & $7.80 \pm 0.10$ & $7.78 \pm 0.14$ & $7.75 \pm 0.11$ \\
\cline { 2 - 5 } & $\mathrm{DO}\left(\mathrm{mg} \cdot \mathrm{L}^{-1}\right)$ & $4.82 \pm 0.38$ & $4.87 \pm 0.31$ & $4.69 \pm 0.29$ \\
\hline
\end{tabular}

Table 2: Average water quality parameters of different treatment of two trials of inducing of M. pancalus.

\section{Breeding Behavior and Spawning}

The different behavior of the species showed during copulation and some of them are presented in the figure 3 . Both male and female changed from whitish-grey to yellowish body color after injected hormone the fish in case of both trials (Figure 3 inset right-down). Courtship begins with the male chasing the female and swimming in a tight circle at $9-10 \mathrm{~h}$ of administration of hormone $\left(1^{\text {st }}\right.$ dose) irrespective of different trials (Figure 3 black arrow). The female and male moved together in anti-clockwise and the female was hold by the male and later bending its body, rubbing, knocking and nudging her (Figure 3 white arrow). Then the pair encircles each other around the roots of the water hyacinths for spawning and it takes place within 15 to $20 \mathrm{~h}$ after administration of $\mathrm{PG}$ hormone. Male releases sperm simultaneously with female and the eggs were fertilized externally. The eggs stick to the root of water hyacinths due to adhesive in nature (Figure 4). They spawned in different batches and took rest about $30 \mathrm{~min}$ after one span of spawning. The swimming movements of the female become slow at the end of the spawning activity and parent take rest at the bottom. The parents were removed from the spawning tank after spawning and noticed that their body color became gradually faded away. The fertilized eggs are spherical and transparent when unfertilized eggs are opaque (Figure 5). The eggs were started to hatch after 36-41 h of spawning.

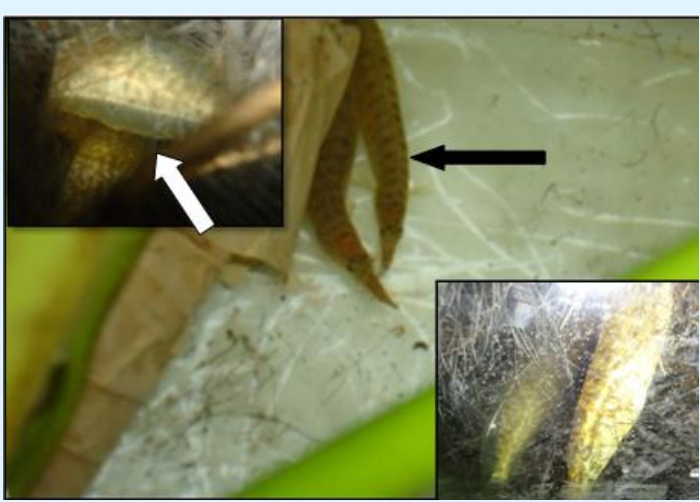

Figure 3: The courtship behabiour of M. pancalus; preparing for mating (black arrow), chaseing anti-clock wise (white arrow) and changing color to yellowish (inset right-down).

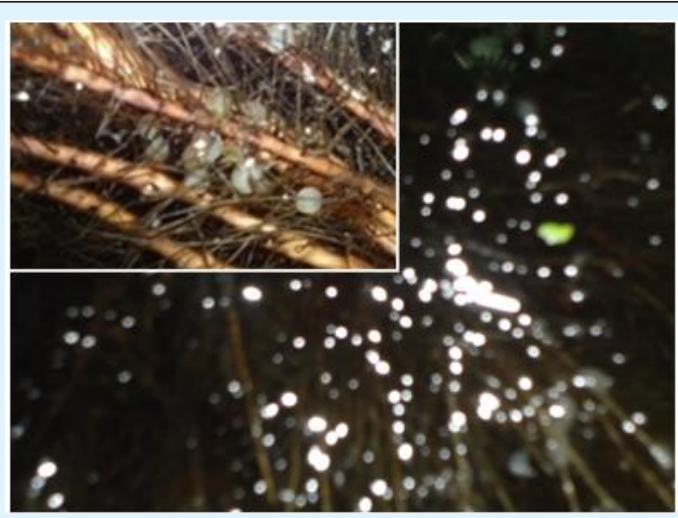

Figure 4: The deposited sticky eggs of $M$. pancalus at the roots of water hyacinths. The adhesive egg in zoom view (inset). 


\section{International Journal of Oceanography \& Aquaculture}

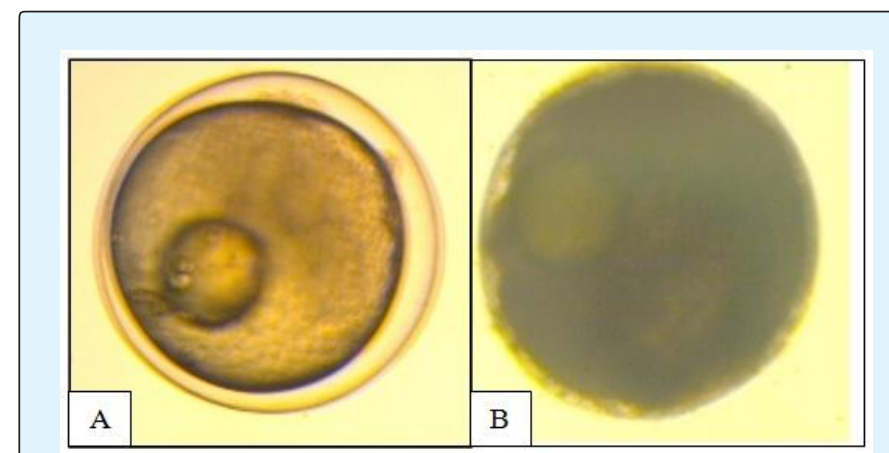

Figure 5: The fertilized (A) and unfertilized (B) egg of $M$. pancalus.

\section{Breeding Performance}

Fishes spawned $100 \%$ in all the treatments at $16-20 \mathrm{~h}$ and 15-19h after hormone administration at 1st trial and $2^{\text {nd }}$ trial respectively (Table 3 ). Incubation period also noticed more or less similar in both trials. The $100 \%$ survival rate of broods noticed in all the treatments of both trials.

\begin{tabular}{|c|c|c|c|c|c|c|}
\hline \multirow[b]{2}{*}{ Trial } & \multirow[b]{2}{*}{$\begin{array}{l}\text { Treat- } \\
\text { ment }\end{array}$} & \multirow{2}{*}{\begin{tabular}{|c|} 
SD* \\
(No/Trea \\
tment)
\end{tabular}} & \multirow[b]{2}{*}{ Spawn } & \multicolumn{2}{|c|}{ Spawnin|Incubatio } & \multirow[b]{2}{*}{$\begin{array}{c}\text { Survival } \\
\text { rate }\end{array}$} \\
\hline & & & & $\begin{array}{l}\text { g time } \\
\text { (h) }\end{array}$ & $\begin{array}{c}\text { n period } \\
\text { (h) }\end{array}$ & \\
\hline \multirow{3}{*}{$\ddot{\omega}$} & $\mathrm{T}_{1}$ & 6 & $100 \%$ & $18-20$ & $39-41$ & $100 \%$ \\
\hline & $\mathrm{T}_{2}$ & 6 & $100 \%$ & $17-19$ & $36-38$ & $100 \%$ \\
\hline & $\mathrm{T}_{3}$ & 6 & $100 \%$ & $16-18$ & $38-41$ & $100 \%$ \\
\hline \multirow{3}{*}{ Zี } & $\mathrm{T}_{1}$ & 6 & $100 \%$ & 18-19 & $38-39$ & $100 \%$ \\
\hline & $\mathrm{T}_{2}$ & 6 & $100 \%$ & $17-18$ & $37-39$ & $100 \%$ \\
\hline & $\mathrm{T}_{3}$ & 6 & $100 \%$ & $15-17$ & $37-40$ & $100 \%$ \\
\hline
\end{tabular}

Table 3: Spawning performance, hours of spawned, incubation time and survival rate of $M$. pancalus through administration of double doses (1st trial) and single dose (2nd trial) of PG extract.

$* \mathrm{SD}=$ stocking density

The mean fertilization rates of M. pancalus in different treatments of two trials at different time intervals are presented in table 4 . The significant $(\mathrm{p}<0.05)$ variation noticed in $\mathrm{T}_{2}$ in both trial compare to other treatments. The highest survival rate $73.33 \pm 5.77 \%$ and $66.67 \pm$ $5.77 \%$ and observed in $\mathrm{T}_{2}$ in 1 st and 2 nd trial respectively.

\begin{tabular}{|c|c|c|c|c|c|c|c|}
\hline Trial & Treatment & $\begin{array}{l}\text { Sampling } \\
\text { time }\end{array}$ & $\begin{array}{c}\text { Observed } \\
\text { number of } \\
\text { eggs }\end{array}$ & $\begin{array}{c}\text { No of fertilized } \\
\text { eggs }\end{array}$ & $\begin{array}{l}\text { Fertilization } \\
\text { rate }(\%)\end{array}$ & $\begin{array}{c}\text { Mean fertilization } \\
\text { (\%) }\end{array}$ & $\begin{array}{c}\text { Mean } \\
\text { fertilization } \\
(\%)\end{array}$ \\
\hline \multirow{3}{*}{$\ddot{\omega}$} & $\mathrm{T}_{1}$ & $\begin{array}{l}2.00 \mathrm{pm} \\
4.00 \mathrm{pm} \\
6.00 \mathrm{pm}\end{array}$ & $\begin{array}{l}10 \\
10 \\
10\end{array}$ & $\begin{array}{l}6 \\
6 \\
5\end{array}$ & $\begin{array}{l}60 \\
60 \\
50\end{array}$ & $56.67 \pm 5.77^{a}$ & \multirow[b]{3}{*}{$64.44 \pm 8.34^{\mathrm{a}}$} \\
\hline & $\mathrm{T}_{2}$ & $\begin{array}{l}2.00 \mathrm{pm} \\
4.00 \mathrm{pm} \\
6.00 \mathrm{pm}\end{array}$ & $\begin{array}{l}10 \\
10 \\
10\end{array}$ & $\begin{array}{l}7 \\
7 \\
8\end{array}$ & $\begin{array}{l}70 \\
70 \\
80\end{array}$ & $73.33 \pm 5.77^{b}$ & \\
\hline & $\mathrm{T}_{3}$ & $\begin{array}{l}2.00 \mathrm{pm} \\
4.00 \mathrm{pm} \\
6.00 \mathrm{pm}\end{array}$ & $\begin{array}{l}10 \\
10 \\
10\end{array}$ & $\begin{array}{l}6 \\
7 \\
6 \\
\end{array}$ & $\begin{array}{l}60 \\
70 \\
60\end{array}$ & $63.33 \pm 5.77 \mathrm{ab}$ & \\
\hline \multirow{3}{*}{ సี } & $\mathrm{T}_{1}$ & $\begin{array}{l}2.00 \mathrm{pm} \\
4.00 \mathrm{pm} \\
6.00 \mathrm{pm}\end{array}$ & $\begin{array}{l}10 \\
10 \\
10\end{array}$ & $\begin{array}{l}5 \\
4 \\
3 \\
\end{array}$ & $\begin{array}{l}50 \\
40 \\
30\end{array}$ & $40.00 \pm 10.0^{\mathrm{a}}$ & \multirow[b]{3}{*}{$55.56 \pm 13.88$} \\
\hline & $\mathrm{T}_{2}$ & $\begin{array}{l}2.00 \mathrm{pm} \\
4.00 \mathrm{pm} \\
6.00 \mathrm{pm}\end{array}$ & $\begin{array}{l}10 \\
10 \\
10\end{array}$ & $\begin{array}{l}6 \\
7 \\
7\end{array}$ & $\begin{array}{l}60 \\
70 \\
70\end{array}$ & $66.67 \pm 5.77^{b}$ & \\
\hline & $\mathrm{T}_{3}$ & $\begin{array}{l}2.00 \mathrm{pm} \\
4.00 \mathrm{pm} \\
6.00 \mathrm{pm}\end{array}$ & $\begin{array}{l}10 \\
10 \\
10\end{array}$ & $\begin{array}{l}6 \\
6 \\
6\end{array}$ & $\begin{array}{l}60 \\
60 \\
60\end{array}$ & $60.00 \pm 00^{\mathrm{b}}$ & \\
\hline
\end{tabular}

Table4: The fertilization rate of M. pancalus at double doses ( $1^{\text {st }}$ trial) and single dose ( $2^{\text {nd }}$ trial) of PG extract.

(Mean $\pm \mathrm{SD}$ ); values of the fertilization rate with different superscripts $(a, b, c)$ differ significantly $(p<0.05)$ in each treatments and trials

Hatching rate was found $41.1 \%, 67.85 \%$ and $57.93 \%$ in treatments of $\mathrm{T}_{1}, \mathrm{~T}_{2}$ and $\mathrm{T}_{3}$ respectively in 1st trial and $41.1 \%, 60.31 \%$ and $55.53 \%$ in $\mathrm{T}_{1}, \mathrm{~T}_{2}$ and $\mathrm{T}_{3}$ respectively in $2^{\text {nd }}$ trial (Table 5). The highest hatching rate was recorded $67.85 \pm 9.44 \%$ in $\mathrm{T}_{2}$ at 1 st trial. The significant $(\mathrm{p}<0.05)$ variation noticed in $\mathrm{T}_{2}$ in both trial compare to other treatments. There was no significant $(\mathrm{p}<0.05)$ variation in terms of hatching rate between 1 st and 2 nd trial. 


\section{International Journal of Oceanography \& Aquaculture}

\begin{tabular}{|c|c|c|c|c|c|c|c|}
\hline Trail & Treat-ment & $\begin{array}{l}\text { Sampling } \\
\text { time }\end{array}$ & $\begin{array}{c}\text { No. of } \\
\text { fertilized } \\
\text { egg }\end{array}$ & $\begin{array}{c}\text { No of } \\
\text { Hatchlings }\end{array}$ & $\begin{array}{c}\text { Hatching } \\
\text { rate (HR; } \\
\%) \\
\end{array}$ & $\begin{array}{l}\text { Mean HR(\%) of } \\
\text { treatments }\end{array}$ & $\begin{array}{c}\text { Mean HR (\%) } \\
\text { of trials }\end{array}$ \\
\hline \multirow{10}{*}{$\stackrel{\hbar}{n}$} & \multirow{4}{*}{$\mathrm{T} 1$} & $7.00 \mathrm{am}$ & 6 & 2 & 33.33 & \multirow{4}{*}{$41.1 \pm 8.39 a$} & \multirow{10}{*}{$55.63 \pm 13.5^{\mathrm{a}}$} \\
\hline & & $9.00 \mathrm{am}$ & 6 & 3 & 50 & & \\
\hline & & $11.00 \mathrm{am}$ & 5 & 2 & 40 & & \\
\hline & & $7.00 \mathrm{am}$ & 7 & 4 & 57.14 & & \\
\hline & \multirow{3}{*}{$\mathrm{T} 2$} & $9.00 \mathrm{am}$ & 7 & 5 & 71.42 & \multirow{3}{*}{$67.85 \pm 9.44^{b}$} & \\
\hline & & $11.00 \mathrm{am}$ & 8 & 6 & 75 & & \\
\hline & & $7.00 \mathrm{am}$ & 6 & 4 & 66.66 & & \\
\hline & \multirow{3}{*}{$\mathrm{T} 3$} & $9.00 \mathrm{am}$ & 7 & 4 & 57.14 & \multirow{3}{*}{$57.93 \pm 8.35^{\mathrm{ab}}$} & \\
\hline & & $11.00 \mathrm{am}$ & 6 & 3 & 50 & & \\
\hline & & $7.00 \mathrm{am}$ & 5 & 2 & 40 & & \\
\hline \multirow{8}{*}{$\stackrel{\vec{J}}{\sim}$} & \multirow{3}{*}{$\mathrm{T} 1$} & $9.00 \mathrm{am}$ & 4 & 2 & 50 & \multirow{3}{*}{$41.1 \pm 8.39^{a}$} & \multirow{8}{*}{$52.31 \pm 10.0^{a}$} \\
\hline & & $11.00 \mathrm{am}$ & 3 & 1 & 33.33 & & \\
\hline & & $7.00 \mathrm{am}$ & 6 & 4 & 66.66 & & \\
\hline & \multirow{3}{*}{$\mathrm{T} 2$} & $9.00 \mathrm{am}$ & 7 & 4 & 57.14 & \multirow{3}{*}{$60.31 \pm 5.49 b$} & \\
\hline & & $11.00 \mathrm{am}$ & 7 & 4 & 57.14 & & \\
\hline & & $7.00 \mathrm{am}$ & 6 & 4 & 66.66 & & \\
\hline & \multirow{2}{*}{$\mathrm{T} 3$} & $9.00 \mathrm{am}$ & 6 & 3 & 50 & \multirow{2}{*}{$55.53 \pm 9.61^{\mathrm{ab}}$} & \\
\hline & & $11.00 \mathrm{am}$ & 6 & 3 & 50 & & \\
\hline
\end{tabular}

Table 5: The hatching rate of M. pancalus at double doses ( $1^{\text {st }}$ trial) and single dose ( $2^{\text {nd }}$ trial) of PG extract.

$\mathrm{HR}=$ hatching rate; (Mean $\pm \mathrm{SD}$ ); values of the hatching rate with different superscripts $(\mathrm{a}, \mathrm{b}, \mathrm{c})$ differ significantly $(p<0.05)$ in each treatments and trials

\section{Discussion}

\section{Water Quality Parameters}

Water quality parameters play an important role in successful breeding. Among them water temperature plays a vital role in gonadal development and timing of the spawning and hatching. If the optimum temperature of the species cannot be maintained the maturation may delay or the eggs may release spasmodically and the total number of egg may also be reduced [19]. The fertilization rate, hatching rate, survival rate, and embryonic development is closely dependent upon the oxygen supply and $\mathrm{pH}$. The dissolved oxygen content of the water should not be below 4 - 5 ppm.

Successful breeding of M. pancalus was performed at an ambient temperature ranged from 26.5 to $31.1^{\circ} \mathrm{C}$ (Table 2) that was suitable for the breeding of M. pancalus which is supported by [20,21] who reported that temperature ranged from 27 to $31^{\circ} \mathrm{C}$ is favored by most of the indigenous small fishes for breeding. This range of temperature is also supported by $[3,6,18]$ for breeding of M. pancalus and they all reported successfully breed within 26-31 ${ }^{\circ} \mathrm{C}$. Besides this, $M$. aculeate us was successfully bred by [22] at 27 to $33^{\circ} \mathrm{C}$ and by [23] at 28 to $30^{\circ} \mathrm{C}$. Thus it may say that water temperature 27 to $31^{\circ} \mathrm{C}$ could be the optimum temperature for breeding of eel fishes. The recorded water $\mathrm{pH}$ and dissolved oxygen varied from 7.06 to 8.04 and 4.10 to $5.6 \mathrm{mg} \cdot \mathrm{L}^{-1}$ in both trials this also supported by $[17,18]$. Afroz, et al. [17] conducted their experiment at 7.13 to 8.69 and 3.6 to 4.9 $\mathrm{mg} \cdot \mathrm{L}^{-1}$ of $\mathrm{pH}$ and DO respectively. Alam, et al. [18] successfully breed M. pancalus at 6.5 to 7.4 and 6.5 to 7.5 $\mathrm{mg} \cdot \mathrm{L}^{-1}$ of $\mathrm{pH}$ and $\mathrm{DO}$ respectively. Hasan, et al. [6] recorded $\mathrm{pH}$ value 7.13 to 8.69 and DO value 3.3 to 5 $\mathrm{mg} \cdot \mathrm{L}^{-1}$.

\section{Breeding Behavior}

The present study recorded yellowish body color of both male and female after hormone administration (Figure 3). This may be due to hormonal effect for the attraction of both sexes each other that help the female to spawn and the male to release milt successfully. Body coloration also has an important role in mate choice. Though there is no such other evidence in color changes of guchiaim, it may compare to other species like [24] recorded orange-red color spot on the operculum of both male and female after hormone administration in case of Puntius chola.

Fishes showed a courtship behavior that is supported by $[3,6]$ for the same species. Fishes showed such 


\section{International Journal of Oceanography \& Aquaculture}

behavior because the reproductive success of fish depends partly on ability to perform correct courtship behavior. The courtship begins with the male chasing the female and swimming in a tight circle. The similar observation was recorded $[6,25,26]$.

In the present study, female and male moved together in anti-clockwise and the female was hold by the male and later bending its body, rubbing, knocking and nudging her. Male hold the female and then bending its body and rubbing to prepare her for spawning and that behavior pattern is supported by $[3,6,22]$. It was also found that during spawning, the male bent its body close to the female and released its milt simultaneously with female and the eggs were fertilized externally.

\section{Breeding Performance}

Pituitary gland (PG) extract was used as the inducing agent for breeding of $M$. pancalus and all the experimental fishes breed successfully (Table 3). Effectiveness of PG in induced breeding of spiny eel is supported by $[3,6,18$, $22]$. The $100 \%$ spawned noticed in the present study by inducing different doses of PG in different phases confirm the effectiveness of PG hormones for the induce breeding of $M$. pancalus.

The courtship and spawning began within 9-10 h and 16-20 $\mathrm{h}$ of hormone administration which was earlier than [16]. They noticed these behaviors at 29-32 $\mathrm{h}$ and 33-35 $\mathrm{h}$ after injecting of different hormones for the same species. The quick spawning occurred in $\mathrm{T}_{3}$ when the high dose $\left(200 \mathrm{mg} \cdot \mathrm{kg}^{-1}\right)$ was applied at a time in the $2 \mathrm{nd}$ trial.
The incubation period of the species was more or less similar in all treatments of both trials and it was within 36-41 h. Rahman et al. [3] recorded incubation period 33$35 \mathrm{~h}$ by carrying out study on induced breeding of $M$. pancalus with PG hormone. However, the little bit shorter incubation period noticed in $\mathrm{T}_{2}$ in both trials where $\mathrm{PG}$ used as medium dose in the present study. So it can be said that secretion of gonadotropins in female occurred quickly at higher dose than that of lower doses but the incubation is depended on other factors.

In average of two trials, it was showed that $100 \%$ spawning performance, $70 \%$ fertilization rate and $64 \%$ hatching rate of $M$. pancalus in medium dose, $180 \mathrm{mg} \cdot \mathrm{kg}^{-1}$ of PG rather than other two doses $\left(160 \mathrm{mg} \cdot \mathrm{kg}^{-1}\right.$ and 200 $\left.\mathrm{mg} \cdot \mathrm{kg}^{-1}\right)$. The findings of the present study showed higher spawning but lower fertilization and hatching rate compare to other such studies on M. pancalus like $[3,18]$. Alam et al. [18] showed $77 \%$ spawning rate, $91 \%$ fertilization rate and $80 \%$ hatching rate while [3] found $90 \%$ spawning rate, $90 \%$ fertilization and $80 \%$ hatching rate (Table 6). Farid et al. [22] reported high fertilization $(86 \%)$ but low hatching rate $(50 \%)$ for the same species using same hormones at different dose. However, low performance reported compare to present findings by [6] and recorded $50 \%$ spawning, 35\% fertilization and $26 \%$ hatching performances by using PG at $60 \mathrm{mg} \cdot \mathrm{kg}^{-1}$ body weight of M. pancalus. There was no prominent variation in terms of spawning and incubation time between 1st and 2nd trials. However, a bit higher fertilization and hatching rate in 1 st trial (double doses) could be suggested for the inducing of the species.

\begin{tabular}{|c|c|c|c|c|}
\hline \multirow{2}{*}{ PG dose (mg·kg-1) } & \multicolumn{3}{|c|}{ Performance } & \multirow{2}{*}{ Reference } \\
\cline { 2 - 4 } & Spawning (\%) & Fertilization (\%) & Hatching (\%) & \multirow{2}{*}{ Farid et al. 2008 } \\
\hline 90 & - & 86 & 50 & Alam et al. 2009 \\
\hline 170 & 77 & 91 & 80 & Rahman et al. 2011 \\
\hline 170 & 90 & 90 & 80 & \multirow{2}{*}{ Prasan et al. 2016 } \\
\hline 60 & 50 & 35 & 26 & \multirow{2}{*}{ Prent study } \\
\hline 160 & 100 & 48.5 & 64 & 57 \\
\hline 180 & 100 & 70 & 51.5 & 54 \\
\hline
\end{tabular}

Table 6: The comparison of breeding performance at different PG dose of the present study with other such studies.

The present findings indicated that the PG extract is effective in induction of M. pancalus under captive condition. The fish responded in all experimental doses but respect to fertilization (73.33\%) and hatching (67.85\%), PG extract at the double dose (60 mg・kg-1 + and $120 \mathrm{mg} \bullet \mathrm{kg}-1$ body weight) could be used as an appropriate dose for induced breeding and seed production of the species.

\section{Acknowledgement}

The present study was financially supported by the Ministry of Education, Peoples Republic of Bangladesh. 


\section{International Journal of Oceanography \& Aquaculture}

We also thank to the fishermen who supported us for collection of brood fishes.

\section{References}

1. (2008) Encyclopedia of Flora and Fauna of Bangladesh. Freshwater Fishes, Aseatic society of Bangladesh, Dhaka 23: 235.

2. Talwar PK, Jhingran AG (1991) Inland fishes of India and adjacent countries Oxford and IBH Publishing Co. PVT. Ltd., New Delhi, India, 2: 789-541.

3. Rahman MM, Miah MI, Hasan KR, Farid SM (2011) Effects of pituitary gland doses on artificial propagation of guchibaim, Mastacembelus pancalus (Hamilton), J Bangladesh Agril Univ 9(2): 305-310.

4. IUCN Bangladesh (2000) Red Book of threatened fishes of Bangladesh, International Union for Conservation of Nature, Bangladesh Country Office, Dhaka, Bangladesh, pp: 116.

5. IUCN Bangladesh (2015) Red List of Bangladesh (5 $5^{\text {th }}$ volume). Freshwater Fishes. IUCN, International Union for Conservation of Nature, Bangladesh Country Office, Dhaka, Bangladesh, pp: 235.

6. Hasan MR, Islam MS, Afroz A, Bahdur P, Akter S (2016) Captive breeding of Striped Spiny Eel, Mastacembelus pancalus (Hamilton, 1822) considering the various hormonal responses. International Journal of Fisheries and Aquatic Studies 4 (3): 7-11.

7. Doha, Hye (1970) Fecundity of Padma river hilsha, Hilsa ilisha (Ham.). Pakistan journal of Science 22: 176-184.

8. Surnar SR, Kamble AD, Walse NS, Sharma OP, Saini VP (2015) Hormone administration with induced spawning of Indian major carp. International Journal of Fisheries and Aquatic Studies 3(1): 1-4.

9. Suresh VR, Biswas BK, Vinci GK, Mitra K, Mukherjee A (2006) Biology and fishery of barred spiny eel, Macrognathus pancalus (Hamilton, 1822). Journal of Acta Ichthyologica Piscatoria 36 (1): 31-37.

10. Karim MA, Hossain A (1972) Studies on the biology of Mastacembelus pancalus (Spiny Eel, Hamilton) in artificial pond. Part II. Sexual maturity and Fecundity. Bangladesh Journal of Biology and Agricultural Sciences 1(2): 15-18.
11. Vettath R, Suresh BK, Biswas GK, Vinci KM, Mukherjee A (2006) Biology and fishery of barried spiny eel, Macrognathus pancalus (Hamilton, 1822). Journal of Acta Ichthyologica Piscatoria 36(1): 31-37.

12. Saha BK, Islam MR, Saha A, Hossain AM (2006) Some aspect of reproduction of the indigenous spiny eel, Mastacembelus pancalus from netrakona, Bangladesh. Bangladesh Journal of Zoology 34(2): 289-293.

13. Pathak BC, Ali R, Serajuddin M (2012) Comparative Analysis of Reproductive Traits in Barred Spiny Eel, Macrognathu pancalus (Hamilton, 1822) from Lotic and Lentic Ecosystems of Gangatic Basin, India. World Journal of Fish and Marine Sciences 4 (5): 470-479.

14. Serajuddin M, Ali R (2005) Food and feeding habits of striped spiny eel, Macrognathus pancalus (Hamilton), Indian Journal of Fisheries 52(1): 81-86.

15. Rahaman MM, Miah MI (2007) Fecundity of guchibaim, Mastacembelus pancalus. J Bangladesh Agril Univ 7(1):133-137.

16. Rahman MM, Miah MI, Taher MA, Hasan MM (2009) Embryonic and larval development of guchibaim, Mastacembelus pancalus (Hamilton). J Bangladesh Agril Univ 7(1): 193-204.

17. Afroz A, Islam MS, Hasan MR, Hasnahena M, Tuly DM (2014) Larval rearing of spiny eel, Mastacembelus pancalus in the captivity with emphasis on their development stages. International Journal of Fisheries and Aquatic Studies 1(6): 163-167.

18. Alam M, Alam MS, Alam MA, Islam MA, Miah MI (2009) Dose optimization with PG hormone for induced breeding of Mastacembelus pancalus. Ecofriendly Agril 2(9): 799-804.

19. Healy MC (1971) Gonadal development and fecundity of the goby Gobobus mimitus. Transaction of the American Fisheries Society 100: 520-526.

20. Islam Z, Chowdhury AQ (1976) Induced spawning of major carp for commercial production of fry in the fish seed farm, Bangladesh Journal of Zoology 4 (2): 51-61.

21. Akhteruzzaman M, Kohinoor AHM, Shah MS (1992) Observations on the induced breeding of Puntius sarana (Hamilton). Bangladesh Journal of Zoology 20 (2): 291-295.
Islam MS and Biswas K. Induced Breeding of Striped Spiny Eel, Mastacembelus Pancalus: Considering Various Doses of Pituitary Gland Hormone. Int J Oceanogr Aquac 2017, 1(4): 000122.
Copyright $@$ Islam MS and Biswas K. 


\section{International Journal of Oceanography \& Aquaculture}

22. Farid SM, Miah MI, Habib MAB, Rahman MM (2008) Effect of pituitary gland (PG) doses on artificial propagation of endangered Tarabaim, Macrognathus aculeatus (BLOCH). Progress Agric 19 (2): 111-118.

23. Das SK, Kalita N (2003) Captive breeding of Peacock Eel, Macrognathus aculeatus. Journal of Aquaculture Asia 3: 17-18.

24. Vincent M, Thomas KJ (2008) Nuptial coloration and courtship behavior during induced breeding of the swamp barb Puntius chola, a freshwater fish. Current science 94 (7): 922-925.

25. Nelson K (1964) The temporal patterning of courtship behavior in the glandulocaudine fishes (Ostariophysi, Characidae). Behavior 24(1): 90-145.

26. Nelson K (1965) After affects the courtship in the male three-spined stickle back. Zeitschrift für vergleichende Physiologie 50: 569-597. 